\title{
Developing a Peace Guidance Book to Alleviate Student Aggressiveness
}

\author{
(Pengembangan Buku Panduan Bimbingan Kedamaian untuk Mereduksi Agresivitas Siswa)
}

\author{
Wahyu Nanda Eka Saputra*, Wike Nurani, Mufied Fauziah \\ Department of Guidance and Counseling, Faculty of Teacher Training and Education, Universitas Ahmad Dahlan, \\ Pramuka St. No. 42, Yogyakarta, Special Region of Yogyakarta, 55161 Indonesia \\ *corresponding author, e-mail: wahyu.saputra@bk.uad.ac.id
}

Article received: February $4^{\text {th }} 2021$; revised: March $12^{\text {th }} 2021$; accepted: April $26^{\text {th }} 2021$

\begin{abstract}
This study aims to develop a peace guidebook as a medium for school counselors in reducing student aggressiveness. The research employed research and development design proposed by Borg and Gall model, which includes identifying aggressive needs and problems, drafting a hypothetical product, and expert and user assessment of the product. The data analysis technique used descriptive analysis to describe the level of aggressiveness. In addition, this study uses Cohens Kappa's inter-rater reliability (IRR) coefficient to identify expert and user agreement on product feasibility. The results of the descriptive analysis show that aggressiveness needs more attention from school counselors, one of which is by implementing peace guidance. The developed guidebook received an assessment from two guidance and counseling experts who have a track record in developing guidance and counseling media. User ratings were obtained from two school counselors who already have educator certificates. Based on expert and user assessments, the peace guidance manual is categorized as suitable for use by school counselors to reduce student aggressiveness. The results of this study should be used as material and consideration for further research to empirically test the peace guidance guidebook's effectiveness in reducing student aggressiveness.
\end{abstract}

Keywords: aggressiveness; peace; peace guidance

\begin{abstract}
Abstrak: Penelitian bertujuan untuk mengembangkan buku panduan bimbingan kedamaian sebagai media bagi konselor sekolah dalam mereduksi agresivitas siswa. Penelitian menggunakan tahapan penelitian dan pengembangan dengan mengadaptasi model Borg dan Gall yang mencakup tiga tahap, yaitu identifikasi kebutuhan dan permasalahan agresivitas, menyusun draf hipotetik produk, dan penilaian ahli serta pengguna terhadap produk. Teknik analisis data menggunakan analisis deskriptif untuk mendeskripsikan tingkat agresivitas. Selain itu, penelitian ini menggunakan inter-rater reliability $(I R R)$ koefisien Cohens's Kappa untuk mengidentifikasi kesepakatan ahli dan pengguna terhadap kelayakan produk. Hasil analisis deskriptif menunjukkan bahwa agresivitas perlu mendapat perhatian lebih dari konselor sekolah, salah satunya dengan mengimplementasikan bimbingan kedamaian. Buku panduan yang dikembangkan mendapat penilaian dari dua ahli bimbingan dan konseling yang memiliki rekam jejak di pengembangan media bimbingan dan konseling. Penilaian dari pengguna diperoleh dari dua konselor sekolah yang telah memiliki sertifikat pendidik. Berdasarkan penilaian ahli dan pengguna, buku panduan bimbingan kedamaian dikategorikan layak digunakan oleh konselor sekolah untuk mereduksi agresivitas siswa. Hasil penelitian ini seyogianya dapat menjadi bahan dan pertimbangan bagi penelitian selanjutnya untuk melakukan uji keefektifan buku panduan bimbingan kedamaian dalam mereduksi agresivitas siswa secara empiris.
\end{abstract}

Kata kunci: agresivitas; kedamaian; bimbingan kedamaian 


\section{INTRODUCTION}

Peace is one of the visions of the present and future education in Indonesia (Kartadinata, 2020). Peace has a positive contribution to students in various aspects. One of the factors that impact the emergence of aggressiveness is the lack of peace of heart and mind in students (Kartadinata et al., 2015). If peace exists within a person, then that person's environment will tend to be peaceful. The study results show that students' inner peace can be the basis for suppressing the urges of oppression and working towards global peace (Cohrs et al., 2013). The results of other studies also show that peace in students can encourage the emergence of a conducive school climate, where students need these comfortable conditions to study (Bradshaw et al., 2014; Cremin \& Bevington, 2017; Saputra, Supriyanto, Kurniawan, Beladina, et al., 2020). Students with a good perception of the school climate can reduce symptoms of depression, experience bullying and acts of violence at school, which can impact adolescent health and well-being (Singla et al., 2020). In addition, the perception of a conducive school climate can also facilitate students to develop their academic performance at school (Gottfredson \& Gottfredson, 1989; Makewa et al., 2011; Saputra, Supriyanto, Astuti, Ayriza, et al., 2020).

This research is motivated by various forms of aggressiveness such as interpersonal conflict, violence between groups, environmental destruction, and human moral decline (Das \& Das, 2014). The results of the study at the Yogyakarta Vocational High School showed that 5\% of students had a very high level of aggressive behavior, $26 \%$ were in the high category, $40 \%$ were in the medium category, $21 \%$ were in a low category, and $8 \%$ were in the very low category (Saputra \& Handaka, 2018). Furthermore, another study related to aggressive behavior at the secondary school level in Yogyakarta showed that students who had very high aggressive behavior were $1 \%, 13 \%$ was in the high category, $37 \%$ was in the medium category, $43 \%$ was in a low category, and the remaining $6 \%$ were in the high very low category (Alhadi et al., 2018). Research findings in Yogyakarta even state that the level of aggressiveness in male and female students has the same tendency (Saputra et al., 2017). Other literature shows that the aggressiveness of male students tends to be reactive and proactive with regard to peers, while the aggressiveness of girls tends to be in the form of romantic relationships (Murray-Close et al., 2010).

The condition of a fairly high aggressive tendency requires efforts from various parties, especially schools to realize the ideals of the state by reducing student aggressiveness. One effort that can be done by school counselors is to implement peace guidance. School counselors as educators play a role as peacemakers and peace movements. The results of the study show that students can take advantage of guidance and counseling services to develop an awareness of peace so that it can encourage the emergence of security (Oguzie, 2014). Another study also reported that group training-based guidance services can develop a sense of gratitude and peace-keeping in students in Aceh, Indonesia (Matunis et al., 2020).

Some research results show that peace guidance services are an alternative effort to reduce student aggressiveness. In previous research, efforts have been recommended to develop peace guidance and counseling that is integrated with Indonesian local wisdom (Supriyanto et al., 2019). One study even recommends an effort to prepare counselors to be successful in creating a culture of peace in various communities (Gerstein \& Moeschberger, 2003). Other literature mentions that the counselor profession is the main agent in promoting a culture of peace both in the school environment and outside the school (Olusakin, 2007). Based on this explanation, an operational guide for implementing peace guidance is needed to help students reduce their aggressiveness.

Peace guidance guide uses the values of peace as a school counselor's capital to help students reduce their aggressiveness. The first study recommends that peace values that can support the guidance of peace include forgiving other people's mistakes, choosing strengths over weaknesses, regulating emotions, and regulating behavior (Saputra, Supriyanto, Astuti, \& Ayriza, 2020). Subsequent research recommends peace values that can support peace guidance, including humility towards idealism, selfcontrol over self-superiority, and tolerance for differences. (Saputra, Ayriza, Supriyanto, \& Astuti, 2020). Based on this explanation, the purpose of this research is to develop and test the acceptability of the product in the form of a peace guidance guide to reduce student aggressiveness. 


\section{METHOD}

\section{Design}

The design in this study used a research and development design (R\&D). This study adopted the Borg and Gall pattern in which the process consists of three stages, namely: (1) identification of the level of aggressiveness which is the basis for developing a hypothetical draft of the guidebook; (2) drafting a hypothetical peace guidance guidebook to reduce aggressiveness; and (3) assessment by guidance and counseling experts, guidance and counseling media experts, and users to assess the feasibility of the product (Borg \& Gall, 1983).

\section{Instrument}

Instruments in this study consisted of two types. The first instrument is an aggressiveness scale consisting of 32 items which are proven valid after testing the validity. The reliability shows a coefficient of 0.870 , which includes a high level of reliability. The second instrument is the assessment sheet of guidance and counseling experts, guidance and counseling media experts, and users to provide product feasibility assessments.

\section{Data Collection}

Identification of student problems using an aggressiveness scale instrument for students of Sekolah Menengah Kejuruan Negeri 6 Yogyakarta (State Vocational High Schools 6 Yogyakarta). Meanwhile, to assess the feasibility of the product, the researcher involved a guidance and counseling expert assessor, namely a lecturer from the guidance and counseling study program who has expertise in the field of guidance and counseling innovation. Furthermore, user assessment is carried out by school counselors who have expertise in providing counseling services to promote behavior change from counselees.

\section{Data Analysis}

This study uses quantitative data analysis. This data analysis is to describe the level of aggressiveness of students at Sekolah Menengah Kejuruan Negeri 6 Yogyakarta (State Vocational High Schools 6 Yogyakarta), so that the level of student aggressiveness can be described, both in the very high, high, medium, low, and very low categories. In addition, this study uses Cohens's Kappa coefficient inter-rater reliability (IRR) analysis to describe the feasibility of the product.

\section{RESULTS}

Based on the research objectives, the research results are described as follows: (1) the level of student aggressiveness; (2) a hypothetical draft of a product in the form of a peace guidance guidebook to reduce student aggressiveness; and (3) the feasibility of the product, namely a peace guidebook to reduce student aggressiveness.

\section{Student Aggressive Level}

Identification of the level of aggressiveness of students at Sekolah Menengah Kejuruan Negeri 6 Yogyakarta (State Vocational High Schools 6 Yogyakarta) using an aggressiveness scale which was then analyzed statistically and descriptively using SPSS. The identification of this level of aggressiveness involved a population of 1301 students. As for the sample, this study involved 275 students randomly. The results of data analysis are presented in table 1 . Based on table 1, the range of scores for the categorization of the results of the aggressiveness scale is in table 2 . Then, the recapitulation of the aggressiveness level measurement is presented in table 3 .

Table 1. Descriptive Statistic

\begin{tabular}{lcccccc}
\hline & N & Minimum & Maximum & Sum & Mean & Std. Deviation \\
\hline VAR00001 & 275 & 32 & 128 & 22000 & 80 & 16 \\
Valid N (listwise) & 275 & & & & & \\
\hline
\end{tabular}


Table 2. Student Aggressiveness Scale Score Range

\begin{tabular}{lc}
\hline Categories & Score Range \\
\hline Very High & $104-128$ \\
High & $88-104$ \\
Medium & $72-88$ \\
Low & $56-72$ \\
Very Low & $32-56$ \\
\hline
\end{tabular}

Table 3. Aggressiveness Level

\begin{tabular}{lcc}
\hline Categories & Number & Percentage \\
\hline Very High & 16 & $5.82 \%$ \\
High & 49 & $17.82 \%$ \\
Medium & 59 & $21.45 \%$ \\
Low & 71 & $25.82 \%$ \\
Very Low & 80 & $29.09 \%$ \\
Total & 275 & $100 \%$ \\
\hline
\end{tabular}

Table 1 shows that the number of samples involved in filling out the aggressiveness scale is 275 students of Sekolah Menengah Kejuruan Negeri 6 Yogyakarta (State Vocational High Schools 6 Yogyakarta). The highest score is 128 and the lowest score is 32 with a standard deviation of 16 . Furthermore, in table 2, the data range of the aggressive category scores of students starting from the very high category is $104-128$, the high category is $88-104$, the medium category is $72-88$, the low category is $56-72$ and the very low category is $32-56$. Based on table 3 , it can be seen that the data on the level of aggressiveness of students at Sekolah Menengah Kejuruan Negeri 6 Yogyakarta (State Vocational High Schools 6 Yogyakarta) is 5.82\% including the very high category, $17.82 \%$ including the high category, $21.45 \%$ including the medium category, $25.82 \%$ including the low category, $29.09 \%$ is in the very low category.

\section{Product Hypothetical Draft}

Peace guidance guidebooks to reduce aggressiveness were developed based on the concept of peace education to reduce conflicts, fights, aggressive behavior, which will lead to peace of mind, both intrapersonally and interpersonally (Kartadinata et al., 2015). The manual includes the following materials: (1) an introduction related to the background, goals of peace guidance, and attributes of a peace counselor; (2) learn to recognize adolescent aggressiveness related to the understanding, forms, causes and effects of aggressiveness; (3) understand the implementation of peace guidance related to understanding, implementation in group guidance, components, and peace guidance strategies; (4) instructions for implementing peace guidance which contains general instructions and specific instructions for implementing peace guidance; and (5) closing related to conclusions and suggestions.

The peace guidance manual has the main purpose of explaining the operational stages of peace guidance in each session. Peace guidance has seven main topics as the theme of discussion in each session: humility towards idealism, self-control over self-superiority, tolerance for differences, forgiving others' mistakes, choosing strengths over weaknesses, regulating self-emotions, and regulating selfbehavior. These seven components are explained in the section on the instructions for implementing peace guidance. The seven themes in the guidance of peace aim to develop peace of mind that can suppress students' aggressiveness. Peace guidance is carried out for 45 minutes per session for seven guidance sessions. The guidebook also contains operational steps at each guidance meeting so that it can make it easier for school counselors to implement them. 


\section{The Feasibility of A Peace Guidance Guidebook to Reduce Student Aggressiveness}

Expert judgments were obtained from guidance and counseling experts, guidance and counseling media experts, and product users. First, this study involved two guidance and counseling experts, namely lecturers from the guidance and counseling study program with expertise in guidance and counseling innovation. Second, this research involves two experts on guidance and counseling media, namely guidance and counseling lecturers who have a track record in guidance and counseling media development. Third, the assessment involves school counselors as product users who have expertise in providing counseling services to promote behavior change from counselees. To identify the feasibility of the product, the researcher used the Cohens's Kappa coefficient inter-rater reliability (IRR) analysis against the agreement of two raters in each area of expertise.

First, the results of the Cohens's Kappa coefficient inter-rater reliability (IRR) analysis based on guidance and counseling experts are presented in table 4. From the test results of the analysis of the coefficient of inter-rater reliability (IRR) from Cohen Kappa in table 4, the value obtained is 0.881 in the very good category. The results obtained indicate that the Cohen Kappa coefficient value indicates there is a good agreement between experts and practitioners regarding the feasibility of the developed media. Asym Std. Error indicates a standardized measurement error, the smaller the magnitude of this coefficient, the more reliable the resulting measurement results. Thus, it can be interpreted that the guidance of peace guidance to reduce aggressiveness is included in the appropriate category to be applied by school counselors based on the assessment of guidance and counseling experts.

In the second part, the results of the inter-rater reliability (IRR) analysis of Cohens's Kappa coefficient are described based on guidance and counseling media experts. The results of the analysis are presented in table 5. Based on the results of the analysis of the coefficient of inter-rater reliability (IRR) from Cohen kappa in table 5, the value obtained is 0.778 in the good category. The results obtained can be interpreted that the Cohens's Kappa coefficient value indicates a good agreement between experts and practitioners regarding the feasibility of the developed media. Asym Std. The error shows a fairly small value, this means that the measurement of peace guidance to reduce aggressiveness which is included in the appropriate category to be applied by counselors in schools based on the assessment of guidance and counseling media experts is reliable.

The third section describes the results of the Cohens's Kappa coefficient inter-rater reliability (IRR) analysis based on users. The results of the analysis are presented in table 6. From the test results of the analysis of the coefficient of inter-rater reliability (IRR) of Cohen Kappa, namely 0.673 in the good category. The results obtained can be interpreted that the Cohen Kappa coefficient value indicates a very good agreement between experts and practitioners regarding the feasibility of the developed media. Asym Std value. Low error indicates reliable measurement results. Thus, it can be interpreted that the peace guidance guide to reduce aggressiveness is included in the appropriate category to be applied by school counselors in schools based on the assessment of users or school counselors.

Table 4. Product Feasibility Analysis Based on Guidance and Counseling Experts

\begin{tabular}{lccccc}
\hline & & Value & Asymp. Std. Error & Approx. T $^{\mathbf{b}}$ & Approx. Sig. $^{\text {Appro }}$ \\
\hline Measure of Agreement & Kappa & .881 & .115 & 3.659 & .000 \\
N of Valid Cases & 17 & & & \\
\hline
\end{tabular}

Table 5. Product Feasibility Analysis Based on Guidance and Counseling Media Experts

\begin{tabular}{|c|c|c|c|c|c|}
\hline & & Value & Asymp. Std. Error ${ }^{a}$ & Approx. $\mathbf{T}^{\mathbf{b}}$ & Approx. Sig. \\
\hline Measure of Agreement & Kappa & .778 & .144 & 3.384 & .001 \\
\hline $\mathrm{N}$ of Valid Cases & & 18 & & & \\
\hline
\end{tabular}

Table 6. Product Feasibility Analysis By A User

\begin{tabular}{|c|c|c|c|c|c|}
\hline & & Value & Asymp. Std. Error ${ }^{a}$ & Approx. $\mathbf{T}^{\mathrm{b}}$ & Approx. Sig. \\
\hline Measure of Agreement & Kappa & .673 & .213 & 2.775 & .006 \\
\hline $\mathrm{N}$ of Valid Cases & & 17 & & & \\
\hline
\end{tabular}




\section{DISCUSSION}

The findings in this study indicate that the guidance guidebooks of peace guidance to reduce aggressiveness is included in the appropriate category based on the assessment by guidance and counseling experts, guidance and counseling media, and users. Peace guidance guidebooks can support school counselor programs in creating a conducive school climate. A conducive school climate has a role in creating a feeling of security and psychological comfort in students (Casey et al., 2017; Voight et al., 2015), so that students can achieve maximum academic achievement at school (Daily et al., 2019; Ruiz et al., 2018).

Peace guidance guidebook uses the value of peace as the guiding theme in each of its meetings. The seven values of peace are humility towards idealism, self-control over self-superiority, tolerance for differences, including forgiving others' mistakes, choosing strengths over weaknesses, regulating self-emotions, and regulating self-behavior (Saputra, Ayriza, Supriyanto, \& Astuti, 2020; Saputra, Supriyanto, Astuti, \& Ayriza, 2020). This product was developed with roots in the theory of peace education which essentially seeks to create positive peace (Cremin \& Bevington, 2017). Positive peace is an attempt to oppose the concept of negative peace by providing physical and psychological resistance that leads to the emergence of aggressive behavior and conflict becomes a condition or state of absence of war or without conflict (Saputra, Supriyanto, Astuti, \& Ayriza, 2020).

The first value of peace is humility towards idealism. No one can deny that students have a tendency to uphold their ideals (Griffith III \& Wilson, 2001; Youde, 2008). Therefore, students need to suppress their idealism to avoid negative impacts such as the desire to express aggressiveness in order to uphold their ideals. One way for students to suppress their idealism is to develop a humble attitude (Asmoko et al., 2020; Nurani et al., 2020; Nurisma et al., 2020).

The second value of peace is self-control over self-superiority. Students who are involved in violence have high self-esteem and believe in their superiority, so they can exploit weak students and make them targets for violent behavior (Marlangan et al., 2020). Therefore, the peace guidebook proposes selfcontrol training to suppress student aggressiveness. Various studies report that a person's ability to control himself can inhibit the emergence of student aggressiveness (Suárez-García et al., 2020; Van Lange et al., 2017).

The third value of peace is tolerance for differences. Indonesia has diverse ethnicities that allow a dispute to occur due to differences of opinion or principles (Kim, 2020). Therefore, peace guidance guidebooks facilitate students to learn tolerance. Some literature reports that the character of tolerance can suppress students' desire to express aggressiveness in the form of violence that is detrimental to various parties, both themselves and others (Saputra et al., 2019; Wijayanti et al., 2020).

The fourth value of peace is to forgive the mistakes of others. Someone who hurts another person is caused by a response to painful behavior from others. At the level of aggressive theory, this is classified as reactive aggressive (Fite et al., 2010; Law et al., 2012; Murray-Close et al., 2010). They do this behavior because they cannot forgive the mistakes of others. Peace guidance guidebooks facilitate counselors to teach about forgiveness. This forgiveness is one of the values of peace that can suppress student aggressiveness (Cristinawati et al., 2020).

The fifth value of peace is choosing strengths over weaknesses. Humans are easier to focus on the bad than the good, and this is included in the category of problematic personality according to the flow of postmodern counseling (Scholl \& Hansen, 2018). School counselors need to facilitate students to find and show the good in themselves rather than having to make a fuss about weaknesses that become insults from others. Students who try to think about their strengths rather than their weaknesses are students who have hope and optimism when facing difficult situations. In simple, hope and optimism are indicators of students who have a philosophy of self-strength (Valle et al., 2006).

The sixth value of peace is to regulate one's emotions. Students' failure to regulate their emotions is one of the causes of the overflow of aggressiveness. Therefore, peace guidance guidebooks provide school counselors with material to train students in emotional regulation. The results of the study report that good student emotional regulation can suppress student aggressiveness (Ersan, 2020). 
The seventh value of peace is to regulate one's behavior. Humans can regulate their behavior according to the desires and values held by these humans (Berkman et al., 2017). Some research results show that one's ability to control one's own behavior has a contribution to the level of aggressiveness (Nakonechnyi \& Galan, 2017). This peace guidebook provides access for school counselors to practice students' self-regulation skills so that students can suppress their aggressiveness.

According to the assessment of guidance and counseling experts as well as guidance and counseling media experts, the seven components have a good contribution to the content of peace guidance media. Espe-cially nowadays, students need to learn the seven components of peace guidance to be able to suppress aggressive urges in themselves. In addition, according to product users, the seven components of peace guidance can be adapted and applied to group guidance and classical guidance services. With the agreement of experts and product users regarding the acceptability of this research product, the product can be used by school counselors to reduce student aggressiveness.

Based on the assessments of two guidance and counseling experts, two guidance and counseling media experts, and two users, the peace guidance guidebook is included in the category suitable for use by school counselors to reduce student aggressiveness. School counselors can take advantage of this research product in an effort to support the success of the program to create a culture of peace in the school environment. This peaceful culture will lead to a conducive school climate in facilitating students to achieve academic achievement (Saputra, Supriyanto, Astuti, Ayriza, et al., 2020).

This research product has limitations. One of the limitations of this product is that there is no available empirical data showing that school counselors who implement this guidebook can reduce student aggressiveness. In addition, empirical data from this study regarding the level of aggressiveness is limited to students of SMK Negeri 6 Yogyakarta (State Vocational High Schools 6 Yogyakarta), so it is possible to identify it more broadly. Another limitation of this research is that there has been no effort to integrate peace guidance with local wisdom, so that further research can utilize elements of local wisdom to support the success of peace guidance.

\section{CONCLUSION}

The peace guidance guidebook that was developed aims to develop peace in students so that they can suppress student aggressiveness. Based on the product feasibility assessment, it can be concluded that this product is feasible and can be used by school counselors as a guide in carrying out peace guidance services to reduce student aggressiveness. This study recommends further research to identify the effectiveness of peaceful guidance to reduce student aggressiveness. In addition, this study also recommends further research to integrate local wisdom in peace guidance.

\section{ACKNOWLEDGMENT}

We wish to thank Kemenristek/Brin, Republic of Indonesia, for funding this research. We also appreciate Universitas Ahmad Dahlan for the endless support during the project commencement.

\section{REFERENCES}

Alhadi, S., Purwadi, P., Muyana, S., Saputra, W. N. E., \& Supriyanto, A. (2018). Agresivitas siswa SMP di Yogyakarta. Jurnal Fokus Konseling, 4(1), 93-99. https://doi.org/10.26638/jfk.507.2099

Asmoko, G. T., Saputra, W. N. E., Alhadi, S., \& Kumara, A. R. (2020). Video perdamaian: Media bimbingan kelompok untuk mereduksi agresivitas. (Webinar) Seminar Nasional Pendidikan 2020, 1(1), $50-055$.

Berkman, E. T., Livingston, J. L., \& Kahn, L. E. (2017). Finding the "self" in self-regulation: The identity-value model. Psychological Inquiry, 28(2-3), 77-98. https://doi.org/10.1080/1047840X.2017.1323463

Borg, W. R., \& Gall, M. D. (1983). Educational research: An introduction. New York: Longman.

Bradshaw, C. P., Waasdorp, T. E., Debnam, K. J., \& Johnson, S. L. (2014). Measuring school climate in high schools: A focus on safety, engagement, and the environment. Journal of School Health, 84(9), 593-604. https://doi.org/10.1111/josh.12186

Casey, T., Griffin, M. A., Flatau Harrison, H., \& Neal, A. (2017). Safety climate and culture: Integrating psychological and systems perspectives. Journal of Occupational Health Psychology, 22(3), 341. https://doi. org/10.1037/ocp0000072 
Cohrs, J. C., Christie, D. J., White, M. P., \& Das, C. (2013). Contributions of positive psychology to peace: Toward global well-being and resilience. American Psychologist, 68(7), 590. https://doi.org/10.1037/a0032089

Cremin, H., \& Bevington, T. (2017). Positive peace in schools: Tackling conflict and creating a culture of peace in the classroom. Routledge.

Cristinawati, R., Saputra, W. N. E., Alhadi, S., \& Kumara, A. R. (2020). Modul latihan forgiveness: Media konselor mereduksi perilaku agresif siswa. (Webinar) Seminar Nasional Pendidikan 2020, 1(1), 136-141.

Daily, S. M., Mann, M. J., Kristjansson, A. L., Smith, M. L., \& Zullig, K. J. (2019). School climate and academic achievement in middle and high school students. Journal of School Health, 89(3), 173-180. https://doi. org/10.1111/josh.12726

Das, S., \& Das, K. K. (2014). Imparting peace education through coscholastic activities at the school level. 1st Multidisciplinary International e-Conference World Peace Day, 25-32.

Ersan, C. (2020). Physical aggression, relational aggression and anger in preschool children: The mediating role of emotion regulation. The Journal of General Psychology, 147(1), 18-42. https://doi.org/10.1080/0022130 9.2019.1609897

Fite, P. J., Raine, A., Stouthamer-Loeber, M., Loeber, R., \& Pardini, D. A. (2010). Reactive and proactive aggression in adolescent males: Examining differential outcomes 10 years later in early adulthood. Criminal Justice and Behavior, 37(2), 141-157. https://doi.org/10.1177/0093854809353051

Gerstein, L.H., \& Moeschberger, S. L. (2003). Building cultures of peace: An urgent task for counseling professionals. Journal of Counseling \& Development, 81(1), 115-119. https://doi.org/10.1002/j.1556-6678.2003.tb00233.x

Gottfredson, G. D., \& Gottfredson, D. C. (1989). School climate, academic performance, attendance, and dropout. Baltimore: Johns Hopkins University. Center for Social Organization of Schools.(ERIC Document Reproduction Service No. ED 308 225).

Griffith III, C. H., \& Wilson, J. F. (2001). The loss of student idealism in the 3rd-year clinical clerkships. Evaluation \& The Health Professions, 24(1), 61-71. https://doi.org/10.1177/01632780122034795

Kartadinata, S. (2020). Mengapa kedamaian? In S. Kartadinata (Ed.), Bimbingan dan konseling komprehensif abad 21: Visi kedamaian dalam kehidupan nyata, eksplorasi akademik 32 tahun, 1988-2020. Bandung: Upi Press.

Kartadinata, S., Affandi, I., Wahyudin, D., \& Ruyadi, Y. (2015). Pendidikan kedamaian. Bandung: Remaja Rosdakarya.

Kim, J. O. (2020). Reanimating historical violence in multi-ethnic graphic narratives. MELUS. https://doi. org/10.1093/melus/mlaa048

Law, D. M., Shapka, J. D., Domene, J. F., \& Gagné, M. H. (2012). Are cyberbullies really bullies? An investigation of reactive and proactive online aggression. Computers in Human Behavior, 28(2), 664-672. https://doi. org/10.1016/j.chb.2011.11.013

Makewa, L. N., Role, E., Role, J., \& Yegoh, E. (2011). School climate and academic performance in high and low achieving schools: Nandi Central District, Kenya. International Journal of Scientific Research in Education, 4(2), 93-104.

Marlangan, F., Suryanti, N. M. N., \& Syafruddin, S. (2020). Kekerasan di sekolah studi pada siswa SMA/SMK di Kota Mataram. Jurnal Pendidikan Sosial Keberagaman, 7(1). https://doi.org/10.29303/juridiksiam.v7i1.113. g57

Matunis, B. A., \& Marsela, F. (2020). The application of group training-based guidance strategies to develop the gratitude of Aceh adolescents in maintaining peace. 2nd International Seminar on Guidance and Counseling 2019 (ISGC 2019), 284-287. https://doi.org/10.2991/assehr.k.200814.062

Murray-Close, D., Ostrov, J. M., Nelson, D. A., Crick, N. R., \& Coccaro, E. F. (2010). Proactive, reactive, and romantic relational aggression in adulthood: Measurement, predictive validity, gender differences, and association with intermittent explosive disorder. Journal of Psychiatric Research, 44(6), 393-404. https:// doi.org/10.1016/j.jpsychires.2009.09.005

Nakonechnyi, I., \& Galan, Y. (2017). Development of behavioural self-regulation of adolescents in the process of mastering martial arts. Journal of Physical Education and Sport, 17, 1002-1008. https://doi.org/10.7752/ jpes.2017.s3154

Nurani, W., Saputra, W. N. E., Mu'arifah, A., \& Barida, M. (2020). Bimbingan kedamaian: Implementasi pendidikan kedamaian dalam seting bimbingan untuk mereduksi agresivitas. (Webinar) Seminar Nasional Pendidikan 2020, 1(1), 178-192.

Nurisma, S. Z., Saputra, W. N. E., Putranti, D., \& Sutanti, T. (2020). Sosiodrama kedamaian: Teknik bimbingan kelompok dalam mereduksi agresivitas siswa pada masa pandemi COVID-19. (Webinar) Seminar Nasional Pendidikan 2020, 1(1), 148-154. 
Oguzie, S. N. (2014). Guidance and counselling services as a coping strategy for inculcating the consciousness of peace, conflict resolution and national security among secondary school youths in Anambra State, Nigeria. African Research Review, 8(2), 256-279. https://doi.org/10.4314/afrrev.v8i2.15

Olusakin, A. M. (2007). Counseling professionals as agents of promoting the cultures of peace. European Journal of Scientific Research, 17(2), 243-257.

Ruiz, L. D., McMahon, S. D., \& Jason, L. A. (2018). The role of neighborhood context and school climate in school-level academic achievement. American Journal of Community Psychology, 61(3-4), 296-309. https:// doi.org/10.1002/ajcp.12234

Saputra, W. N. E., Ayriza, Y., Supriyanto, A., \& Astuti, B. (2020). The Indonesians’ peaceful mind: A gadamerian hermeneutic study of the Markesot bertutur. 1st International Conference on Folklore, Language, Education and Exhibition (ICOFLEX 2019), 275-279. https://doi.org/10.2991/assehr.k.201230.052

Saputra, W. N. E., \& Handaka, I. B. (2018). Perilaku agresi pada siswa SMK di Yogyakarta. Jurnal Fokus Konseling, 4(1), 1-8. https://doi.org/10.26638/jfk.475.2099

Saputra, W. N. E., Hanifah, N., \& Widagdo, D. N. (2017). Perbedaan tingkat perilaku agresi berdasarkan jenis kelamin pada siswa sekolah menengah kejuruan Kota Yogyakarta. Jurnal Kajian Bimbingan dan Konseling, 2(4), 142-147. https://doi.org/10.17977/um001v2i42017p142

Saputra, W. N. E., Supriyanto, A., Astuti, B., \& Ayriza, Y. (2019). Bimbingan kedamaian: Strategi konselor untuk mereduksi agresivitas. K-Media.

Saputra, W. N. E., Supriyanto, A., Astuti, B., \& Ayriza, Y. (2020). Pikiran damai berdasarkan penuturan Markesot: Studi hermeneutika teks Markesot bertutur lagi. Jurnal Kajian Bimbingan dan Konseling, 5(2), 80-90. http:// dx.doi.org/10.17977/um001v5i22020p080

Saputra, W. N. E., Supriyanto, A., Astuti, B., Ayriza, Y., \& Adiputra, S. (2020). The effect of student perception of negative school climate on poor academic performance of students in Indonesia. International Journal of Learning, Teaching and Educational Research, 19(2), 279-291. https://doi.org/10.26803/ijlter.19.2.17

Saputra, W. N. E., Supriyanto, A., Kurniawan, S. J., Beladina, S. S., Astuti, B., \& Ayriza, Y. (2020). Konsep kedamaian diri remaja pada masa pandemi COVID-19. (Webinar) Seminar Nasional Pendidikan 2020, 1(1), 172-177.

Scholl, M., \& Hansen, J. (2018). Postmodern perspectives on contemporary counseling issues: Approaches across diverse settings. Oxford University Press.

Singla, D. R., Shinde, S., Patton, G., \& Patel, V. (2021). The mediating effect of school climate on adolescent mental health: Findings from a randomized controlled trial of a school-wide intervention. Journal of Adolescent Health, 69(1), 90-99. https://doi.org/10.1016/j.jadohealth.2020.09.030

Suárez-García, Z., Álvarez-García, D., García-Redondo, P., \& Rodríguez, C. (2020). The effect of a mindfulnessbased intervention on attention, self-control, and aggressiveness in primary school pupils. International Journal of Environmental Research and Public Health, 17(7), 2447. https://doi.org/10.3390/ijerph17072447

Supriyanto, A., Saputra, W., \& Astuti, B. (2019). Peace guidance and counseling based on Indonesian local wisdom. Proceedings of the 2019 Ahmad Dahlan International Conference Series on Education \& Learning, Social Science \& Humanities (ADICS-ELSSH 2019). Yogyakarta, Indonesia. https://doi.org/10.2991/adicselssh-19.2019.37

Valle, M. F., Huebner, E. S., \& Suldo, S. M. (2006). An analysis of hope as a psychological strength. Journal of School Psychology, 44(5), 393-406. https://doi.org/10.1016/j.jsp.2006.03.005

Van Lange, P. A., Rinderu, M. I., \& Bushman, B. J. (2017). Aggression and violence around the world: A model of Climate, Aggression, and Self-control in Humans (CLASH). Behavioral and Brain Sciences, 40, 1-58. https://doi.org/10.1017/S0140525X16000406

Voight, A., Hanson, T., O’Malley, M., \& Adekanye, L. (2015). The racial school climate gap: Within-school disparities in students' experiences of safety, support, and connectedness. American Journal of Community Psychology, 56(3), 252-267. https://doi.org/10.1007/s10464-015-9751-X

Wijayanti, R. N., Saputra, W. N. E., Hartanto, D., \& Nugraha, A. (2020). Modul berpikir damai (media konselor mereduksi perilaku agresif siswa pada masa pandemi COVID-19). (Webinar) Seminar Nasional Pendidikan 2020, 1(1), 121-127.

Youde, J. (2008). Crushing their dreams? Simulations and student idealism. International Studies Perspectives, 9(3), 348-356. https://doi.org/10.1111/j.1528-3585.2008.00340.x 